\title{
DAMPAK MOTIVASI, DISIPLIN KERJA DAN KEPEMIMPINAN KEPALA SEKOLAH TERHADAP KINERJA GURU
}

\section{IMPACT OF MOTIVATION, WORK DISCIPLINE AND SCHOOL HEAD LEADERSHIP ON TEACHER PERFORMANCE}

\author{
Sya'roni, Toni Herlambang, Dwi Cahyono \\ Program Studi Magister Manajemen Program Pascasarjana \\ Universitas Muhammadiyah Jember \\ Email: syaroni046@gmail.com, toniherlambang@unmuhjember.ac.id, \\ dwicahyono@unmuhjember.ac.id
}

\begin{abstract}
ABSTRAK
Tujuan dari penelitian ini adalah untuk menganalisis motivasi, disiplin kerja, dan kepemimpinan kepala sekolah secara parsial maupun simultan terhadap kinerja guru SMK Swasta di Kecamatan Tempeh. Metode penelitian menggunakan pendekatan kuantitatif. Dengan jumlah populasinya adalah semua guru SMK Swasta Kecamatan Tempeh Lumajang sebanyak 53 orang guru dan kepala sekolah. Untuk pengumpulan data menggunakan kuisioner. Teknik analisis data menggunakan teknik analisis regresi. Hasil penelitian ini adalah: (1) koefisien motivasi sebesar 0.239 menunjukkan bahwa motivasi memiliki pengaruh positif terhadap kinerja guru, yang berarti semakin tinggi motivasi seorang guru maka kinerja guru tersebut juga akan semakin meningkat, (2) disiplin kerja memiliki nilai koefisien sebesar 0.266 , menunjukkan bahwa disiplin kerja memiliki pengaruh positif terhadap kinerja guru, yang berarti semakin disiplin seorang guru dalam melaksanakan pekerjaannya maka kinerja guru tersebut juga akan semakin meningkat, (3) Koefisien kepemimpinan sebesar 0.333 menunjukkan bahwa kepemimpinan kepala sekolah memiliki pengaruh positif terhadap kinerja guru, yang berarti jika kepemimpinan kepala sekolah semakin baik maka akan meningkatkan kinerja guru, (4) secara konstanta sebesar 0.741 menunjukkan besarnya kinerja guru ketika motivasi, disiplin kerja dan kepemimpinan tidak diperhatikan oleh pihak sekolah. Jadi apabila motivasi, disiplin kerja dan kepemimpinan tidak diperhatikan oleh pihak sekolah, kinerja guru masih ada sebesar $74.1 \%$.
\end{abstract}

Kata Kunci : motivasi, disiplin kerja, kepemimpinan kepala sekolah dan kinerja guru

\begin{abstract}
The purpose of this study is to analyze motivation, work discipline, and leadership of principals partially or simultaneously on the performance of teachers of Private Vocational Schools in Tempeh District. The research method uses a quantitative approach. With the total population, all 53 teachers and principals from Tempeh Subdistrict Lumajang Sub-district Vocational School. For data collection using questionnaires. The data analysis technique uses regression analysis techniques. The results of this study are: (1) motivation coefficient of 0.239 indicates that motivation has a positive influence on teacher performance, which means that the higher the motivation of a teacher, the teacher's performance will also increase, (2) work discipline has a coefficient of 0.266 , indicating that work discipline has a positive influence on teacher performance, which means that the more disciplined a teacher in carrying out his work, the teacher's performance will also increase, (3) The leadership coefficient of 0.333 indicates that the principal's leadership has a positive influence on teacher performance, which means if Principal leadership is getting better so it will improve teacher performance, (4) Constantly 0.741 shows the amount of teacher performance when motivation, work discipline and leadership are not considered by the school. So if
\end{abstract}


motivation, work discipline and leadership are not considered by the school, the teacher's performance still exists at $74.1 \%$.

Keywords: motivation, work discipline, principal leadership and teacher performance

\section{PENDAHULUAN}

Pendidikan merupakan wahana yang sangat strategis dalam meningkatkan kualitas sumber daya manusia yang merupakan faktor determinan pembangunan. Pendidikan adalah usaha sadar untuk menyiapkan peserta didik melalui kegiatan bimbingan, pengajaran, dan atau latihan bagi peranannya di masa yang akan datang (UU SPN No. 20 Tahun 2003). Dengan tidak bermaksud mengecilkan kontribusi komponen yang lainnya, komponen tenaga kependidikan atau guru merupakan salah satu faktor yang sangat esensi dalam menentukan kualitas peserta didiknya Pendidikan adalah modal dasar untuk menciptakan SDM yang unggul. Dunia pendidikan yang utama adalah sekolah. Sekolah merupakan salah satu lembaga alternatif pelayanan pendidikan. Sekolah sebagai suatu lembaga tentunya memiliki visi, misi, tujuan dan fungsi. Untuk mengemban misi, mewujudkan visi, mencapai tujuan, dan menjalankan fungsi sekolah memerlukan tenaga profesional, tata kerja organisasi dan sumber-sumber yang mendukung baik finansial maupun nonfinansial.

Sekolah adalah sebuah lembaga yang dirancang untuk pengajaran siswa atau murid di bawah pengawasan pendidik atau guru. Sebagian besar negara memiliki sistem pendidikan formal yang umumnya wajib dalam upaya menciptakan anak didik yang mengalami kemajuan setelah mengalami proses melalui pembelajaran (Safaina \& Idi, 2011:142). Sekolah sebagai suatu sistem memiliki komponen-komponen yang berkaitan satu sama lain serta berkontribusi pada pencapaian tujuan. Komponen-komponen tersebut adalah siswa, kurikulum, bahan ajar, guru, kepala sekolah, tenaga kependidikan lainnya, lingkungan, sarana, fasilitas, proses pembelajaran dan hasil atau output.

Guru merupakan salah satu SDM yang berada di sekolah. Kinerja guru di sekolah mempunyai peran penting dalam pencapaian tujuan sekolah. Masalah kinerja menjadi sorotan berbagai pihak, kinerja pemerintah akan dirasakan oleh masyarakat dan kinerja guru akan dirasakan oleh siswa atau orang tua siswa. Berbagai usaha dilakukan untuk mencapai kinerja yang baik. Guru harus benar-benar kompeten dibidangnya dan guru juga harus mampu mengabdi secara optimal. Kinerja guru yang optimal dipengaruhi oleh berbagai faktor, baik internal maupun eksternal. 
Selain itu guru diposisikan sebagai garda terdepan di dalam pelaksanaan proses belajar mengajar karena guru memegang posisi yang sangat strategis dalam upaya menciptakan lulusan yang kompeten dan berkualitas untuk memenuhi kebutuhan SDM yang professional. UU No. 14 Tahun 2005 Bab IV pasal 20 (a) tentang guru dan dosen menyatakan bahwa standar prestasi kerja guru dalam melaksanakan tugas keprofesionalannya, guru berkewajiban merencanakan pembelajaran, melaksanakan proses pembelajaran yang bermutu serta menilai dan mengevaluasi hasil pembelajaran. Tugas pokok guru tersebut yang diwujudkan dalam kegiatan belajar mengajar merupakan bentuk kinerja guru.

Menurut Prawirosentono dalam Sutrisno (2011:170) kinerja adalah hasil kerja yang dapat dicapai oleh seseorang atau dari kelompok orang dalam suatu organisasi, sesuai dengan wewenang dan tanggung jawab masing-masing dalam rangka upaya mencapai tujuan organisasi bersangkutan secara legal, tidak melanggar hukum dan sesuai dengan norma maupun etika. Robbins dan Judge (2012:145) menyatakan bahwa peningkatan kinerja karyawan akan membawa kemajuan bagi perusahaan untuk dapat bertahan dalam suatu persaingan lingkungan bisnis yang tidak stabil. Oleh karena itu upaya-upaya untuk meningkatkan kinerja karyawan merupakan tantangan manajemen yang paling serius karena keberhasilan untuk mencapai tujuan dan kelangsungan hidup perusahaan tergantung pada kualitas kinerja sumber daya manusia yang ada didalamnya.

Guru mengajar karena ada sesuatu yang memotivasi dirinya untuk bekerja. Motivasi kerja ini yang menyebabkan seorang guru untuk bersemangat dalam menjalankan tugas sebagai pendidik karena telah terpenuhi kebutuhannya. Pemenuhan kebutuhan tersebut berkaitan dengan kepuasan kerja, dimana antara harapan guru terpenuhi oleh kenyataan yang diberikan organisasi. Thoha (2004:206) mengemukakan bahwa istilah motivasi terkadang dipakai silih berganti dengan istilah lainnya, seperti kebutuhan, keinginan, dorongan, semangat atau impuls. Perilaku manusia itu hakekatnya adalah berorientasi pada tujuan dengan kata lain bahwa perilaku seseorang itu pada umumnya dirangsang oleh keinginan untuk mencapai beberapa tujuan. Robbin (2003:208) mengatakan bahwa suatu proses yang menghasilkan suatu intensitas, arah dan ketekunan individual dalam usaha untuk mencapai satu tujuan. Sementara motivasi umum bersangkutan dengan upaya ke arah setiap tujuan sehingga akan menguatkan 
kinerja karyawan. Penelitian Kaliri (2008:125) yang membuktikan motivasi kerja berpengaruh signifikan terhadap kinerja guru.

Kinerja guru juga dipengaruhi oleh kedisiplinan dari guru tersebut. Guru merupakan panutan bagi siswa-siswanya, sehingga sudah sepatutnya guru memiliki kedisiplinan yang tinggi. Rivai (2011:123) menyatakan bahwa disiplin kerja adalah suatu alat yang digunakan para manajer untuk berkomunikasi dengan karyawan agar mereka bersedia untuk mengubah suatu perilaku sebagai suatu upaya untuk meningkatkan kesadaran dan kesediaan seseorang mematuhi semua peraturan perusahaan dan normanorma sosial yang berlaku. Jadi dapat disimpulkan bahwa disiplin kerja adalah suatu usaha dari manajemen organisasi perusahaan untuk menerapkan atau menjalankan peraturan ataupun ketentuan yang harus dipatuhi oleh setiap karyawan tanpa terkecuali. Penelitian Kaliri (2008:125) yang membuktikan disiplin kerja berpengaruh signifikan terhadap kinerja guru.

Selain itu kepemimpinan kepala sekolah merupakan hal yang dapat mendorong peningkatan kinerja guru. Hasibuan (2001:167) kepemimpinan adalah cara seorang pemimpin mempengaruhi perilaku bawahannya, agar mau bekerja sama dan bekerja secara produktif untuk mencapai tujuan organisasi. Kepemimpinan adalah suatu seni atau kemampuan dalam mempengaruhi dan menggerakkan staf yang dalam hal ini pegawai agar bisa menjalankan tugas dengan penuh tanggung jawab. Pemimpin lah yang bertanggung jawab didalam menciptakan lingkungan kerja yang kondusif dan aman sehingga orang-orang dapat bekerja dengan penuh semangat. Penelitian Arimbi (2011:25) membuktikan bahwa kepemimpinan memiliki pengaruh yang signifikan terhadap kinerja guru.

Sekolah Menengah Kejuruan (SMK) di Kabupaten Lumajang terdiri dari 9 sekolah negeri dan 25 sekolah swasta. Di kecamatan Tempeh terdiri dari 1 SMK Negeri dan 3 SMK Swasta. Penelitian ini dilakukan pada SMK Swasta di Kecamatan Tempeh, yakni terdiri dari SMK Mulia Tempeh, SMK Asy Syarifiy Tempeh dan SMK Mamba'ul Hikmah Pulo Tempeh. Pada SMK tersebut terdapat indikasi kurangnya motivasi, disiplin kerja, kepemimpinan kepala sekolah terhadap kinerja guru.

Kinerja guru Sekolah Menengah Kejuruan di Kecamatan Tempeh, salah satunya dapat dilihat dari tingkat kehadiran guru. Dari data absensi banyak guru yang menghiraukan untuk mengisi kehadirannya disekolah, semangat untuk mengajar 
disekolah kurang disebabkan kurangnya motivasi kerja. Masih rendah nya kinerja guru seperti mengajar tidak sesuai dengan kompetensinya, struktur tugas yang tidak jelas, jadwal kerja yang tumpang tindih. Seorang guru harus memiliki persyaratan-persyaratan khusus, mengetahui landasan pendidikan untuk mentransformasikan informasi maupun pelajaran kepada siswa. Meskipun demi kian guru bukanlah satu-satunya sumber informasi di dalam kelas, siswa harus diberi kesempatan untuk mengembangkan diri. Tugas guru yang utama bukan lagi menyampaikan pengetahuan melainkan memupuk pengertian, membimbing mereka untuk belajar sendiri. Kemampuan untuk menemukan sendiri dan belajar sendiri diangkap dapat dipelajari.

Guru sebagai tenaga professional seharusnya memiliki pengetahuan dan pengalaman di bidangnya. Guru yang memiliki pengetahuan dan pengalaman yang cukup dalam bidangnya akan mampu melihat kedepan dalam peningkatan perkembangan unit pelayanan teknis. Kinerja guru dapat dilihat dari penguasaan guru terhadap kompetensi yang dimiliki sebagai tenaga professional. Banyak faktor yang mempengaruhi kinerja guru, diantaranya adalah kompetensi yang memadai dan wajar, kondisi kerja yang aman dan sehat, kesempatan untuk mengembangkan kemam puan, rasa ikut memiliki, motivasi kerja, disiplin kerja dan lain-lain. Namun dalam penelitian ini, hanya akan meneliti kinerja guru yang dipengaruhi oleh motivasi kerja dan disiplin kerja.

Dalam kasus pada SMK swasta kecamatan tempeh yang sedang berusaha mencapai status Sekolah Standar Nasional (SSN) masih banyak hal yang harus ditingkatkan, baik dari kinerja guru, kedisiplinan, motivasi kerja, sampai gaya kepemimpinan kepala sekolah. Fakta menunjukkan tingkat kedisiplinan guru di SMK swasta masih rendah. Hal ini dapat dilihat dari absensi (kehadiran/ketidak hadiran) dari guru. Dari data yang ada diketahui bahwa setiap bulannya pada ketiga SMK Swasta di Kecamatan Tempeh selalu terdapat kasus ketidakhadiran. Salah satu syarat agar disiplin dapat ditumbuhkan dalam lingkungan kerja ialah, adanya pembagian kerja yang tuntas sampai kepada pegawai atau petugas yang paling bawah, sehingga setiap orang tahu dengan sadar apa tugasnya, bagaimana melakukannya, kapan pekerjaan dimulai dan selesai, seperti apa hasil kerja yang diinginkan, dan kepada siapa mempertang gungjawabkan hasil pekerjaan itu. Tanpa adanya disiplin yang baik, jangan harap akan dapat diwujudkan ada nya sosok pemimpin sebagaimana yang diharapkan oleh organisasi dan masya rakat. Kinerja guru sangat diperlu kan 
untuk mencapai tujuan organisasi. Hal tersebut sangat berkaitan dengan beberapa faktor yang mempengaruhinya, seperti kepemim pinan, motivasi, dan disiplin kerja guru karena tanpa kepemimpinan yang baik, motivasi yang ada serta disiplin kerja yang bagus dari guru akan sulit dicapai kinerja guru yang diharapkan dalam organisasi.

Dari uraian yang telah dijelaskan maka tujuan dari penelitian ini adalah sebagai berikut :

1. Untuk mengetahui pengaruh motivasi terhadap kinerja guru SMK swasta di Kecamatan Tempeh Kab. Lumajang.

2. Untuk mengetahui pengaruh disiplin kerja terhadap kinerja guru SMK swasta di Kecamatan Tempeh Kab. Lumajang.

3. Untuk mengetahui pengaruh kepemimpinan kepala sekolah terhadap kinerja guru SMK swasta di Kecamatan Tempeh Kab. Lumajang.

4. Untuk mengetahui pengaruh motivasi, disiplin kerja, dan kepemimpinan kepala sekolah terhadap kinerja guru SMK swasta di Kecamatan Tempeh Kab. Lumajang.

\section{TINJAUAN PUSTAKA}

\section{Motivasi}

Motivasi berasal dari bahasa latin movere yang berarti dorongan atau penggerakan. Secara umum motivasi dapat diartikan sebagai dorongan dan keinginan serta upaya yang muncul dari diri seorang individu untuk melakukan suatu hal. Robbins (2002:55) dalam Brahmasari dan Suprayetno (2008:125) mengemukakan bahwa motivasi adalah keinginan untuk melakukan sebagai kesediaan untuk mengeluarkan tingkat upaya yang tinggi untuk tujuan organisasi, yang dikondisikan oleh kemampuan upaya itu untuk memenuhi suatu kebutuhan individual. Achmad Slamet (2007:125) menjelaskan bahwa motivasi adalah proses psikologis yang mendasar dan merupakan salah satu unsure yang dapat menjelaskan perilaku seseorang. Motivasi merupakan dorongan yang dapat membuat seseorang meningkatkan kinerjanya (Azhad, dkk. 2015).

\section{Disiplin Kerja}

Menurut Saydam (2000:23) menyatakan disiplin merupakan kemampuan untuk menguasai diri sendiri dan melaksanakan norma-norma yang berlaku dalam kehidupan, mentaati tata cara yang telah ditentukan dalam kehidupan, mentaati tata cara yang telah ditentukan dalam melaksanakan tugas dan tanggung jawab yang telah diserahkan kepada 
setiap orang sehingga dapat dijalankan dengan penuh kesadaran. Robbins dalam Achmad Slamet (2007:216) adalah suatu sikap dan perilaku yang dilakukan secara sukarela dengan penuh kesadaran dan kesediaan mengikuti peraturan-peraturan yang telah ditetapkan oleh organisasi atau atasan, baik tertulis maupun tidak tertulis

\section{Kepemimpinan}

Menurut Hasibuan (2005:170), bahwa kepemimpinan adalah seni seorang pemimpin mempengaruhi bawahannya, agar mau bekerjasama dan bekerja secara produktif untuk mencapai tujuan organisasi. Menurut Terry (2003:5) : "Leader ship is activity of influence people to strive wilingly for matual objectives“, Kepemimpinan adalah keseluruhan kegiatan untuk mempengaruhi orang lain untuk mencapai tujuan bersama.

\section{Kinerja guru}

Kinerja merupakan hasil atau keluaran dari suatu proses. Dikatakan lebih lanjut oleh Mulyasa bahwa kinerja atau performance dapat diartikan sebagai prestasi kerja, pelaksanaan kerja, pencapaian kerja, hasil-hasil kerja atau unjuk kerja. Dessler (1997:513) menyatakan pengertian kinerja hampir sama dengan prestasi kerja ialah perbandingan antara hasil kerja actual dengan standar kerja yang ditetapkan. Dalam hal ini kinerja lebih memfokuskan pada hasil kerja.

\section{METODE PENELITIAN}

\section{Desain Penelitian}

Menurut Supranto (2001:237) desain penelitian pada dasarnya untuk menentukan metode apa saja yang akan dipergunakan dalam penelitian. Sedangkan Kerlingger (2004:483) mengungkapkan bahwa desain penelitian atau rancang bangun penelitian adalah rencana dan struktur (model/paradigma) penyeli dikan yang disusun sedemikian rupa untuk memperoleh jawaban atas pertanyaan- pertanyaan penelitian.

\section{Populasi dan Sampel}

Populasi dalam penelitian ini adalah seluruh guru SMK Swasta di Kecamatan Tempeh Kabupaten Lumajang yang berjumlah 53 orang termasuk Kepala Sekolah dan guru tetap yayasan (GTY). Mempertimbangkan jumlah populasi di bawah seratus orang maka penelitian ini menggunakan seluruh populasi sebagai responden, artinya teknik sampling yang diambil adalah teknik sensus. 


\section{Uji Validitas}

Uji validitas digunakan untuk mengetahui sah atau valid tidaknya suatu kuesioner, suatu kuesioner dinyatakan valid jika pertanyaan pada kuesioner mampu untuk mengungkapkan sesuatu yang akan diukur oleh kuesioner tersebut (Ghozali, 2013:52). Mengukur validitas dapat dilakukan dengan cara melakukan korelasi bivariate antara masing-masing skor indikator dengan total skor konstruk atau variabel. Apabila korelasi masing-masing skor pertanyaan dengan skor total menunjukkan hasil yang signifikan atau kurang dari $\alpha=0,05$ maka kuisioner dikatakan valid.

\section{Uji Reliabilitas}

Reabilitas adalah alat untuk mengukur suatu kuisioner yang merupakan indikator dari variabel atau konstruk. Suatu kuisioner dikatakan reliabel atau handal jika jawaban seseorang terhadap pernyataan adalah konsisten atau stabil dari waktu ke waktu (Ghozali, 2013:47). Uji reliabilitas dilakukan dengan menggunakan uji statistik Cronbach Alpha. Suatu instrument dapat dikatakan reliabel atau handal bila nilai Cronbach Alpha lebih besar dari 0,7 .

\section{Analisis Regresi Linier Berganda}

Analisis linear regresi digunakan untuk melakukan prediksi, bagaimana perubahan nilai variabel dependen bila nilai variabel independen dinaikan atau diturunkan nilainya (Sugiyono, 2010:149). Selain itu analisis ini digunakan untuk mengetahui arah hubungan antara variabel independen dengan variabel dependen apakah masing-masing variabel independen berhubungan positif atau negatif. Berikut formulasi regresi linier berganda pada penelitian ini:

$$
\mathrm{Y}=\mathrm{a}+\mathrm{b} 1 \mathrm{X} 1+\mathrm{b} 2 \mathrm{X} 2+\mathrm{b} 3 \mathrm{X} 3+\mathrm{e}
$$

\section{Analisis Koefisien Determinasi}

Koefisien determinasi (R2) pada intinya mengukur seberapa jauh kemampuan model dalam menerangkan variasi variable terikat. Nilai koefisien determinasi adalah antara nol dan satu. Nilai (R2) yang kecil berarti kemampuan variabel-variabel independen dalam menjelaskan variasi variabel dependen amat terbatas. Begitu pula sebaliknya, nilai yang mendekati satu berarti variabel-variabel independen memberikan hampir semua informasi yang di butuhkan untuk memprediksi variasi variabel dependen (Ghozali, 2013:97). 


\section{HASIL DAN PEMBAHASAN}

\section{Deskriptif Responden}

Data deskriptif yang menggambarkan keadaan atau kondisi responden merupakan informasi tambahan untuk memahami hasil-hasil penelitian. Responden dalam penelitian ini memiliki karakteristik. Jumlah responden berdasarkan jenis kelamin, terdiri atas responden pria sebanyak 21 guru atau 39.6\% dan responden wanita sebanyak 32 guru atau $60.4 \%$. Responden berdasarkan usia terdiri dari responden berusia $\geq 45$ tahun sebanyak 13 guru, responden berusia 35-44 tahun sebanyak 22 guru dan responden berusia 25-34 tahun sebanyak 18 guru. Responden berdasarkan pendidikan dapat diketahui bahwa $91 \%$ memiliki ijazah pendidkan terakhir strata satu, dengan jumlah 48 guru. Sedangkan sebanyak 9\% memiliki ijazah pendidkan terakhir strata dua, dengan jumlah 5 guru. Responden berdasarkan lama bekerja dapat diketahui bahwa responden yang bekerja kurang dari 10 tahun berjumlah 7 karyawan atau $13.2 \%$, bekerja antara 11 sampai 20 tahun berjumlah 6 karyawan atau 11.3\%, bekerja antara 21 sampai 30 tahun berjumlah 23 karyawan atau 43.4\% dan yang bekerja lebih dari 30 tahun berjumlah 17 karyawan atau $32.1 \%$.

\section{Analisis Regresi Linier Berganda}

Analisis regresi linier berganda dilakukan untuk mengetahui adanya hubungan secara linier antara variabel dependen dengan variabel-variabel independen. Analisis ini digunakan untuk memprediksi nilai dari variabel dependen apabila nilai variabel independen mengalami kenaikan atau penurunan Ghozali (2009:85)

Tabel 1. Hasil Analisis Regresi Berganda

\begin{tabular}{lll}
\hline No & Variabel & Koefisien \\
\hline 1 & Konstanta & 0.741 \\
2 & Motivasi & 0.239 \\
3 & Disiplin Kerja & 0.266 \\
4 & Kepemimpinan & 0.333 \\
\hline
\end{tabular}

Sumber: Data Diolah.

Konstanta sebesar 0.741 atau $74.1 \%$ menunjukkan besarnya kinerja guru ketika motivasi, disiplin kerja dan kepemimpinan tidak diperhatikan oleh pihak sekolah. Koefisien motivasi sebesar 0.239 menunjukkan bahwa motivasi memiliki pengaruh 
positif terhadap kinerja guru, yang berarti semakin tinggi motivasi seorang guru maka kinerja guru tersebut juga akan semakin meningkat. Koefisien kepemimpinan sebesar 0.333 menunjukkan bahwa kepemimpinan kepala sekolah memiliki pengaruh positif terhadap kinerja guru, yang berarti jika kepemimpinan kepala sekolah semakin baik maka akan meningkatkan kinerja guru. Disiplin kerja memiliki nilai koefisien sebesar 0.266, menunjukkan bahwa disiplin kerja memiliki pengaruh positif terhadap kinerja guru, yang berarti semakin disiplin seorang guru dalam melaksanakan pekerjaannya maka kinerja guru tersebut juga akan semakin meningkat.

\section{Uji Hipotesis}

\section{Tabel 2. Hasil Uji Hipotesis}

\begin{tabular}{llllll}
\hline \multirow{2}{*}{ Variabel } & Uji t & \multicolumn{5}{l}{ Uji F } \\
\cline { 2 - 6 } Motivasi & Sig. & & $\alpha$ & Sig. & $\alpha$ \\
Disiplin Kerja & 0.037 & $<$ & 0.05 & & \\
Kepemimpinan & 0.025 & $<$ & 0.05 & $0.000<0.05$ \\
\hline
\end{tabular}

Sumber : Data Diolah.

Hipotesis pertama menunjukkan motivasi mempunyai nilai signifikansi hitung sebesar 0.037 lebih kecil dari 0.05, sehingga hipotesis pertama diterima. Hasil ini membuktikan motivasi memiliki pengaruh yang signifikan terhadap kinerja guru. Disiplin kerja mempunyai nilai signifikansi hitung sebesar 0.025 lebih kecil dari 0.05 , sehingga hipotesis kedua diterima. Hasil ini membuktikan disiplin kerja berpengaruh signifikan terhadap kinerja guru. Kepemimpinan mempunyai nilai signifikansi hitung sebesar 0.001 lebih kecil dari 0.05, sehingga hipotesis ketiga diterima. Hasil ini membuktikan kepemimpinan memiliki pengaruh yang signifikan terhadap kinerja guru. Hasil uji simultan menunjukkan nilai signifikansi 0,000 lebih kecil dari taraf signifikansi $(0,000<$ 0,05), maka hipotesis keempat diterima dan dapat disimpulkan bahwa motivasi, disiplin kerja dan kepemimpinan berpengaruh signifikan terhadap kinerja guru.

\section{Analisis Koefisien Determinasi}

Koefisien determinasi merupakan besaran yang menunjukkan besarnya variasi variabel dependen yang dapat dijelaskan oleh variabel independennya. Nilai Adjusted $R$ Square sebesar 0.512 menunjukan bahwa 51.2\% kinerja guru pada SMK Swasta di Kecamatan Tempeh Lumajang dipengaruhi oleh motivasi, disiplin kerja dan 
kepemimpinan. Sedangkan sisanya $48.2 \%$ dipengaruhi oleh variabel lain diluar model atau persamaan, seperti lingkungan kerja, kompensasi dan lain-lain.

\section{Pembahasan}

\section{Pengaruh Motivasi Terhadap Kinerja Guru}

Hasil pengujian hipotesis telah membuktikan motivasi berpengaruh positif signifikan terhadap kinerja guru. Melalui hasil perhitungan yang telah dilakukan diperoleh nilai signifikansi hitung sebesar 0,037 lebih kecil dari 0,05 yang berarti hipotesis diterima. Pengujian secara statistik ini menunjukkan jika guru memiliki motivasi yang tinggi dalam melaksanakan pekeraannya maka kinerja guru akan semakin baik. Motivasi guru merupakan dorongan bagi guru tersebut untuk melaksanakan dan menyelesaikan pekerjaannya dengan sebaik-baiknya. Hal itu akan terjadi jika guru menyenangi pekerjaan mereka. Terbukti bahwa mayoritas responden menyatakan bahwa mereka senang dengan pekerjaannya. Selain itu guru yang memiliki keinginan menjadi lebih baik dari guru yang lain akan meningkatkan kemampuan dirinya, sehingga secara tidak langsung kinerja guru akan mengalami peningkatan.

Hasil ini sesuai dengan pernyataan Hal ini sesuai dengan pendapat Terry (2003:66) motivasi sebagai kebutuhan sekaligus sebagai pendorong bagi pegawai untuk melakukan tindakan-tindakan sehingga tujuan yang di inginkan dapat tercapai. Faktor motivasi memiliki hubungan langsung dengan kinerja individual pegawai. Robbins (2006:238) seorang karyawan akan bersedia melakukan upaya yang lebih besar apabila diyakininya bahwa upaya itu akan berakibat pada penilaian kinerja yang baik dan penilaian kinerja yang baik akan berakibat pada kenaikan gaji serta promosi. Artinya motivasi karyawan terhadap hal yang mereka inginkan membuat karyawan bersedia melakukan pekerjaan dengan lebih baik. Hasil ini juga didukung oleh penelitian Kaliri (2008:125) yang membuktikan motivasi kerja berpengaruh signifikan terhadap kinerja guru. Pada objek penelitian yang berbeda Kaliri (2008:125) juga membuktikan bahwa motivasi memilki pengaruh yang signifikan terhadap kinerja pegawai.

\section{Pengaruh Disiplin Kerja Terhadap Kinerja Guru}

Hasil pengujian hipotesis telah membuktikan terdapat pengaruh positif signifikan disiplin kerja terhadap kinerja guru. Melalui hasil perhitungan yang telah dilakukan diperoleh nilai signifikansi sebesar 0.025 lebih kecil dari 0.05 , yang berarti hipotesis 
diterima. Hasil penelitian ini membuktikan bahwa semakin tinggi kedisiplinan seorang guru maka akan meningkatkan kinerja guru pada tiga SMK Swasta di Kecamatan Tempeh Lumajang. Guru merupakan panutan bagi siswa-siswanya, sehingga sudah sepatutnya guru memiliki kedisiplinan yang tinggi. Bukan hanya siswa, guru juga mengikuti dan menerapkan semua peraturan yang telah ditetapkan oleh sekolah. Kedisiplinan tersebut dibuktikan dengan beberapa hal, salah satunya adalah ketepatan waktu dalam melaksanakan pekerjaan. SMK Swasta di Kecamatan Tempeh memiliki aturan yang ketat terhadap keterlampatan. Sehingga tidak heran jika guru selalu datang ke sekolah tepat waktu dan mengajar sesuai jadwal mengajar yang diberikan oleh pihak sekolah. Ketepatan waktu tersebut membuat kinerja guru semakin baik.

Hasil penelitian ini sesuai dengan pernyataan Hasibuan (2010:154) bahwa disiplin dalam bekerja merupakan faktor yang harus pula dimiliki oleh karyawan yang menginginkan tercapainya kinerja yang baik dalam pekerjaannya. Disiplin kerja dapat berupa ketepatan waktu dalam kerja, ketaatan terhadap tugas-tugas yang diberikan kepadanya, serta pemanfaatan sarana secara baik. Paradigma organisasi saat ini yang ingin berkembang dan maju sangat membutuhkan karyawan yang berdisiplin tinggi dalam pekerjaannya. Hasil penelitian ini juga didukung oleh penelitian Kaliri (2008:125) yang membuktikan disiplin kerja berpengaruh signifikan terhadap kinerja guru. Pada objek penelitian yang berbeda Pratama (2011:109) juga membuktikan bahwa disiplin kerja memilki pengaruh yang signifikan terhadap kinerja pegawai.

\section{Pengaruh Kepemimpinan Terhadap Kinerja Guru}

Pengaruh kepemimpinan pada tiga SMK Swasta di Kecamatan Tempeh Lumajang telah terbukti memiliki pengaruh yang signifikan terhadap kinerja guru. Melalui hasil perhitungan yang telah dilakukan diperoleh nilai signifikansi sebesar 0,001 lebih kecil dari 0.05 yang berarti hipotesis diterima. Hasil ini membuktikan bahwa jika kepemimpinan Kepala Sekolah semakin baik maka akan meningkatkan kinerja guru. Kepala Sekolah adalah seorang guru yang diberikan tugas tambahan untuk memimpin suatu sekolah. Segala kebijakan yang diterapkan di sekolah harus mendapatkan persetujuan dari kepala sekolah. Sehingga kepala sekolah dituntut untuk memiliki kemampuan dalam mengendalikan emosi setiap menghadapi suatu masalah. Guru SMK Swasta di Kecamatan Tempeh sangat mengharapkan sosok pemimpin yang baik. Mereka 
menjelaskan bahwa jika kepala sekolah memiliki perhatian yang tinggi terhadap sekolah dan guru, maka mereka akan semakin semangat untuk bekerja sehingga kinerjanya pun akan semakin yang baik.

Hasil ini sesuai dengan pernyataan Kadarman dan Jusuf (2001:34) yang menyatakan bahwa tugas seorang pemimpin adalah mendorong bawahannya untuk mencapai tujuan. Jadi dalam memimpin pasti terlibat kemampuan seseorang untuk mempengaruhi atau memotivasi orang lain atau bawahannya agar mereka mau melaksanakan tugas yang diberikan kepadanya dengan baik. Seorang manajer membujuk atau mempengaruhi bawahannya untuk bertindak secara organisatoris dengan cara tertentu agar dapat menghasilkan kinerja yang efektif. Pernyataan tersebut didukung oleh Siagian (2003:103) bahwa kepemimpinan memainkan peranan yang sangat dominan pada keberhasilan organisasi dalam menyelenggarakan berbagai kegiatannya terutama terlihat dalam kinerja para pegawainya. Hasil penelitian diperkuat oleh Arimbi (2011:98) \& Kaliri (2008: 109) membuktikan bahwa kepemimpinan memiliki pengaruh yang signifikan terhadap kinerja guru. Pada objek penelitian yang berbeda Pratama (2011:89) dan Sukmasari (2011:96) juga membuktikan bahwa motivasi kerja berpengaruh signifikan terhadap kinerja pegawai.

\section{KESIMPULAN}

Berdasarkan pengujian secara statistik, maka dapat ditarik kesimpulan sebagai berikut:

1. Motivasi memiliki pengaruh positif signifikan terhadap kinerja guru pada tiga SMK Swasta di Kecamatan Tempeh Lumajang. Hal ini menunjukkan semakin jika guru memiliki motivasi yang tinggi dalam melaksanakan pekerjaannya maka kinerja guru akan semakin baik.

Disiplin kerja memiliki pengaruh positif signifikan terhadap kinerja guru pada tiga SMK Swasta di Kecamatan Tempeh Lumajang. Hal ini menunjukkan semakin tinggi kedisiplinan seorang guru maka akan meningkatkan kinerja guru pada tiga SMK Swasta di Kecamatan Tempeh Lumajang.

2. Kepemimpinan kepala sekolah memiliki pengaruh positif signifikan terhadap kinerja guru. Hal ini menunjukkan jika kepemim pinan kepala sekolah semakin baik maka akan meningkatkan kinerja guru pada tiga SMK Swasta di Kecamatan Tempeh Lumajang. 
3. Secara simultan motivasi, disiplin kerja dan kepemimpinan memiliki pengaruh signifikan terhadap kinerja guru. Pengaruh yang diberikan ketiga variabel bebas tersebut bersifat positif artinya semakin baik motivasi, disiplin kerja dan kepemimpinan akan meningkatkan kinerja guru pada tiga SMK Swasta di Kecamatan Tempeh Lumajang.

\section{Saran}

1.SMK Swasta di Kecamatan Tempeh perlu memperhatikan motivasi, disiplin kerja dan kepemimpinan untuk meningkatkan kinerja guru, karena pada analisis koefisien determinasi menunjukkan ketiga variabael tersebut memiliki pengaruh yang cukup besar terhadap kinera guru SMK Swasta di Kecamatan Tempeh, Lumajang.

2.Kepala sekolah harus lebih memperhatikan tugas dan tanggung jawabnya, karena masih terdapat responden yang menyatakan bahwa kepemimpinan kepala sekolah kurang baik. Selain meningkatkan kualitas diri sebagai pemimpin di sekolah, kepala sekolah perlu mengadakatan pendekatan-pendekatan yang sifatnya persuasif terhadap para guru.

3.Berdasarkan hasil penelitian terdapat beberapa saran yang dapat diberikan bagi peneliti selanjutnya. Peneliti selanjutnya diharap dapat menambah jumlah responden agar hasil penelitian dapat lebih representatif atau mewakili populasi. Jumlah responden dapat ditambah dengan menambah jumlah objek penelitian, yakni dengan menambah sekolah negeri atau sekolah pada kecamatan lain.

4.Hasil analisis koefisien determinasi menunjukkan bahwa masih terdapat variabel lain yang harus diperhatikan dalam penelitian ini. Penelitian selanjutnya hendaknya menambahkan variabel lain yang dapat mempengaruhi kinerja guru, karena masih banyak variabel lain yang dapat mempengaruhi kinerja guru, seperti lingkungan kerja, kepuasan kerja, kompensasi dan lain-lain.

\section{DAFTAR PUSTAKA}

Alma, Buchari. 2003. Manajemen Pemasaran dan Pemasaran Jasa. CV. Alfabeta, Bandung.

Arimbi, Vela Miarri Nurma. 2011. Pengaruh Kepemimpinan Kepala Sekolah Terhadap Kinerja Guru Sekolah Menengah Kejuruan (SMK) Negeri Di Temanggung. Tesis Fakultas Ilmu Pendidikan, Universitas Negeri Yogyakarta. (Tidak Dipublikasikan).

Azhad, M. Naely, Anwar, Nurul Qomariah. 2015. Manajemen Sumberdaya Manusia. Jember. Cahaya Ilmu. 
Bernardin, H, J dan Russel, J,E,A. 1998 Human Resource Management: An Experential Approach 2/e. Me Graw Hill, Singapore.

Brahmasari, Ida Ayu dan Agus Suprayetno. 2008. Pengaruh Motivasi Kerja, Kepemimpinan, dan Budaya Organisasi Terhadap Kepuasan Kerja Karyawan serta Dampaknya pada Kinerja Perusahaan (Studi kasus pada PT. Pei Hei International Wiratama Indonesia). Jurnal Manajemen dan Kewirausahaan. Vol. 10.

Buchori Zainun. 2004. Manajemen dan Motivasi. Balai Aksara, Jakarta.

Dessler, Gary. 2009. Manajemen SDM buku 1. Indeks Jakarta.

E. Mulyasa, (2009), Menjadi Kepala Sekolah Profesional. PT Remaja Rosdakarya. Bandung.

Ghozali, Imam. 2013. Aplikasi Analisis Multivariate Dengan Program SPSS 21. Edisi Ketujuh. Universitas Diponegoro, Semarang.

Handoko, T. Hani. 2003. Manajemen Edisi 2 . BPFE. Yogyakarta.

Hasibuan, Malayu S. P. 2001. Manajemen Sumber Daya Manusia. PT. Bumi Aksara, Jakarta.

Hasibuan, Malayu S. P. 2003. Manajemen Sumber Daya Manusia. Edisi Revisi. PT. Bumi Aksara, Jakarta.

Hasibuan, Malayu S.P. 2005. Manajemen Sumber Daya Manusia, Edisi Revisi. PT. Bumi Aksara, Jakarta.

Kaliri. 2008. Pengaruh Disiplin Dan Motivasi Kerja Terhadap Kinerja Guru Pada SMA Negeri Di Kabupaten Pemalang. Tesis Magister Manajemen Pendidikan, Universitas Negeri Semarang (Tidak Dipublikasikan).

Kerlinger, Fred. N. (2004), Asas-Asas Penelitian Behavioral, Gajah Mada University Press, Yogyakarta.

Nawawi, Hadari. 2007. Manajemen Sumber Daya Manusia Untuk Bisnis Yang Kompetitif. Gajah Mada Univerity Press, Yogyakarta.

Mangkunegara, A. A, Anwar Prabu. 2011. Manajemen Sumber Daya Manusia Perusahaan. PT. Remaja Rosdakarya, Bandung.

Maslow, Abraham H. 1994. Motivasi dan Kepribadian (Teori Motivasi dengan. Pendekatan Hierarki Kebutuhan Manusia). PT. Pustaka. Binaman Pressindo, Jakarta.

Moenir, A. S. 2002. Manajemen Pelayanan Umum Indonesia. Bumi Aksara. Jakarta. 
Pratama, Maizar, 2011. Pengaruh Kepemimpinan, Motivasi Kerja, Dan Disiplin Kerja Terhadap Kinerja Pegawai Balai Wilayah Sungai Sumatera V. Jurnal Fakultas Ekonomi, Universitas Tamansiswa Padang.

Prijatna, Hendra, 2011. Pengaruh Kepemimpinan Kepala Sekolah, Motivasi Kerja, Disiplin Kerja Terhadap Kinerja Guru Pada SMPN 1 Cisarua Kabupaten Bandung Barat Tahun Pelajaran 2010/2011. Tesis UPI Bandung (Tidak Dipublikasikan).

Rahman at all, (2006), Peran Strategis Kepala Sekolah dalam Meningkatkan Mutu Pendidikan, Alqaprint. Jatinangor.

Rivai, Veithzal. 2011. Manajemen Sumber Daya Manusia untuk Perusahaan: dari Teori ke Praktik. Raja Grafindo Persada, Jakarta.

Ridwan, Malik. 2002. Teori motivasi dan Aplikasi. Rineka Cipta, Jakarta.

Robbins, Stephen P. (2003). Perilaku organisasi. PT. Indeks, Jakarta.

Robbin, S. P. dan Judge Timothy. 2012. Perilaku Organisasi. Salemba Empat, Jakarta.

Safaina, H. D. dan Abdullah Idi. 2011. Sosiologi pendidikan. Raja Grafindo Persada, Jakarta.

Saydam, Gouzali. 2000. Manajemen Sumber Daya Manusia (Human Resource Suatu Pendekatan Mikro. Djanbatan, Jakarta.

Setiyawan, Purnomo Budhi dan Waridin. 2007. Pengaruh Disiplin Kerja Karyawan dan Budaya Organisasi Terhadap Kinerja Di Divisi Radiologi RSUP Dokter Kariadi Semarang. Jurnal Riset Bisnis Indonesia. Vol 2. No 2.

Siagian, Sondang P. (2002), Kiat Meningkatkan Produktivitas Kerja. Rineka Jaya. Jakarta.

Simamora, Henry. 2007. Manajemen Sumber Daya Manusia. STIE YKPN. Yogyakarta.

Slamet, Achmad 2007. Manajemen Sumber Daya Manusia. Unnes Press, Semarang.

Soedjono, 2000, Strategi Sumber Daya Manusia, Jakarta Vol. 4, No. 4.

Sugiyono. 2010. Metode Penelitian Kuantitatif Kualitatif dan R\&D. Alfabeta, Bandung.

Sukmasari, Hentry. 2011. Pengaruh Kepemimpinan, Motivasi, Insentif, Lingkungan Kerja, Dan Kepuasan Kerja Terhadap Kinerja Pegawai Dinas Pengelolaan Keuangan Dan Aset Daerah Kota Semarang. Tesis Universitas Dian Nuswantoro, Semarang (Tidak Dipublikasikan).

Sutrisno, Edy. 2009. Manajemen Sumber Daya Manusia. Edisi pertama. Kencana Prenada Media Group, Jakarta. 
Sutrisno, Edy. 2011. Manajemen Sumber Daya Manusia. Kencana Prenada Media Group, Jakarta.

Terry R, George. 2003. Prinsip-prinsip Manajemen, Bumi Aksara, Jakarta.

Toha, Miftah. 2004. Kepemimpinan Dalam Manajemen. PT. Raja Grafindo Persada, Jakarta.

Uno, Hamzah. B. 2009. Teori Motivasi \& Pengukurannya. Bumi Aksara, Jakarta.

UU SPN No. 20 Tahun 2003. Sistem Pendidikan Nasional. Presiden RI, Jakarta.

UU No. 14 Tahun 2005. Guru dan Dosen. Menkumham, Jakarta.

Veithzal, Rivai. 2005. Kepemimpinan Dan Perilaku Organisasi, PT. Raja Grafindo Persada, Jakarta.

Wahjosumijo, (2002), Kepemimpinan Kepala Sekolah, PT Raja Grafindo Persada. Jakarta. 